\title{
RECENT REPORTS ON PYRAZOLE-BASED BIOACTIVE COMPOUNDS AS CANDIDATE FOR ANTICANCER AGENTS
}

\author{
BAYU ARDIANSAH*
}

Department of Chemistry, FMIPA, Universitas Indonesia, Depok, 16424, Indonesia. Email: bayu.ardiansah@sci.ui.ac.id

Received: 17 August 2017, Revised and Accepted: 13 October 2017

\section{ABSTRACT}

Pyrazole is a five-membered heterocyclic compound containing two nitrogen atoms. Due to its biological significance, design of novel pyrazole derivatives has become an interesting research area. We report the current progress in the development of anticancer agents containing pyrazole ring covering the time span of the past few years (2013-2016). The presence of this nucleus is accompanied with some side chains, functional groups, or in combination with other nucleus such as thiazole, thiourea, glucosamine, naphthalimide, and benzofuran. Several biologically active pyrazoles synthesized by numerous researchers across the world are summarized in this paper.

Keywords: N-heterocyclic, Pyrazole, Synthetic derivatives, Anticancer agents.

(C) 2017 The Authors. Published by Innovare Academic Sciences Pvt Ltd. This is an open access article under the CC BY license (http://creativecommons. org/licenses/by/4. 0/) DOI: http://dx.doi.org/10.22159/ajpcr.2017.v10i12.22065

\section{INTRODUCTION}

$\mathrm{N}$-containing heterocycles are molecules which have unique structural motif and found extensively in natural products such as hormones, alkaloids, and vitamins [1,2]. Pyrazole represents one of the most prominent classes of heterocycles exhibiting large spectrum of biological performances such as anticancer [3,4], antitumor [5], anti-AIDS [6], antimicrobial [7,8], antimalarial [9], and antitubercular [10]. It gained great attention since the privileged structure is commonly found as active constituent in commercial drugs (Fig. 1), such as lonazolac 1 nonsteroidal anti-inflammatory drug (NSAID), pyrazofurin 2 (anticancer), difenamizole 3 (analgesic), and deracoxib 4 (NSAID) [11-14]. The simplicity of preparation and rich of biological benefits of pyrazole and its derivatives make them as interesting platform chemicals for organic, medicinal, and pharmaceutical chemistry.

Chemically, in the basic structure, pyrazole has two nitrogen atoms at adjacent position in the five-membered ring [15]. Molecular formula of pyrazole is $\mathrm{C}_{3} \mathrm{H}_{4} \mathrm{~N}_{2}$ which has $6 \pi$ electrons delocalized in ring forms an aromatic system. Pyrazole is closely linked with several of its reduced or oxidized form such as pyrazoline, pyrazolidine, and pyrazolone (Fig. 2). Unlike pyrazole, pyrazoline, and pyrazolidine are not aromatic compounds due to lack of conjugation and delocalization of $\pi$ electrons. The main skeletal of pyrazole and its related structures can be utilized as important building blocks in organic synthetic for the design of a variety of biologically active compounds $[16,17]$. In this review, we collect research result about the potency of pyrazole derivatives as anticancer agents.

\section{DISCUSSION}

With the shift in the people's living habit, cancer has become a deadly disease in both developed and developing countries across the globe [18]. It is caused by miss-regulation or mutation of the cell cycle that regulate genes and proteins. Cancer is a group of various diseases, i.e., lung cancer, cervical cancer, prostate cancer, and breast cancer, and all of them are characterized by an abnormal control of cell growth [19]. Despite many clinically successful anticancer drugs have been developed either natural products or synthetic derivatives of naturally occurring lead compounds, there are still limitations in the treatment of cancer including the effectiveness of drugs and serious side effects [20]. Hence, many pyrazole-based compounds have been synthesized and screened by scientists.
Discovery of some pyrazoles in the year 2013

Molecular structures of pyrazole derivatives prepared by several research group during 2013 were presented in Fig. 3. Some new compounds of pyrazole-based 1,3-thiazoles and 1,3,4-thiadiazoles were synthesized by Dawood et al. and evaluated for anticancer activity against HepG2, MCF-7, and A549 cell lines [21]. Following in vitro evaluation, it was reported that there are 9 compounds (9a-c, 10a-b, 11, and $12 \mathrm{a}-\mathrm{c}$ ) that have $\mathrm{IC}_{50}$ values below $100 \mu \mathrm{M}$. Compound 9a showed anticancer potency with IC $\mathrm{I}_{50}$ value of $67.11 \mu \mathrm{M}$ against HepG2 cell line but inactive against MCF-7 and A549 cell lines. Introduction of electron donating group (4-Me and 4-OMe) to compounds $9 \mathrm{~b}$ and $9 \mathrm{c}$ enhanced their anticancer activity with $\mathrm{IC}_{50}$ range of 20.74-64.50 $\mu \mathrm{M}$ against the aforementioned cancer cell lines. Compounds $10 \mathrm{a}$ and $10 \mathrm{~b}\left(\mathrm{IC}_{50}\right.$ values between 8-16 $\mu \mathrm{M}$ ) were reported as the most active compounds of the series against three model cancer cell lines. They have greater activity compared to compounds 11 and $12 \mathrm{a}-\mathrm{c}$ [21]. A new series of pyrazolebased acyl thiourea derivatives synthesized by Koca et al. was screened for their anticancer potential against DLD-1, HepG2, and Jurkat cell lines [22]. Compounds $13 \mathrm{a}-\mathrm{k}$ have shown good anticancer activity which has \% cell viability after $48 \mathrm{~h}$ in the range of 6.00-90.00 (against Jurkat cell line), 40.25-96.56 (against DLD-1 cell line), and 20.81-51.24 (against HepG2 cell line). Compound 13a is the most potent pyrazole in this series which has $6.00 \pm 0.61 \%$ cell viability against Jurkat cell line at sample concentration of $10^{-4} \mathrm{M}[22]$.

El-Gamal et al. developed novel structures bearing triarylpyrazole scaffold and determined their anticancer performance [23]. Surprisingly, all tested compounds (14a-m) demonstrated superior anticancer activity against over 60 cancer cell lines including RPMI-8226, HOP-92, KM12, SF-295, MDA-MB-435, OVCAR-3, A498, PC-3, and MDA-MB-468. Triarylpyrazole $14 \mathrm{~h}$ was reported as the most active anticancer agent with $\mathrm{IC}_{50} \leq 0.63 \mu \mathrm{M}$ [23]. Another series of pyrazole derivatives in the form of 2-oxo- $2 \mathrm{H}$-chromenylpyrazolecarboxylates $15 \mathrm{a}$-c and $16 \mathrm{a}$-d with a potent performance against prostate (DU-145), lung adenocarcinoma (A549), and cervical (HeLa) cancer cell lines was described by Kumar et al. [24]. These compounds displayed appreciable anticancer potency against all the tested cell lines with $\mathrm{IC}_{50}$ values between 24 and $40 \mu \mathrm{M}$ (on DU-149), 18-52 $\mu \mathrm{M}$ (on A549), and 22-50 $\mu \mathrm{M}$ (on HeLa).

Thirty derivatives of pyrazole and pyrazoline bearing isosteviol moiety (17a-17ad) were synthesized by Zhu et al. [25]. The cytotoxic activities were evaluated in vitro against four human cancer cell 


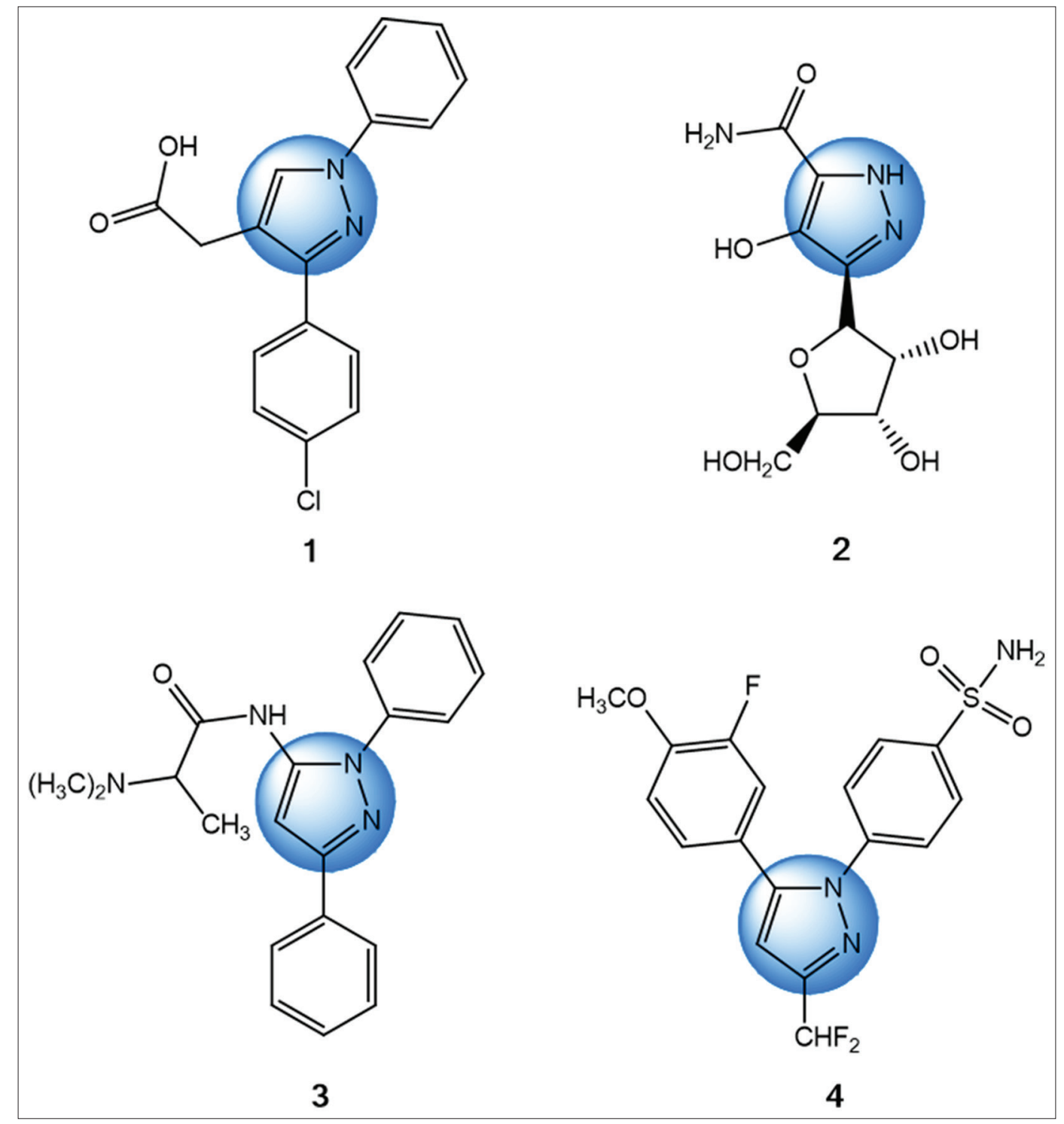

Fig. 1: Several commercial drugs containing pyrazole ring<smiles>c1cn[nH]c1</smiles>

pyrazole (5)<smiles>C1=NNCC1</smiles>

or<smiles>C1=CNNC1</smiles>

pyrazoline (6)<smiles>C1CNNC1</smiles><smiles>O=C1C=CN=N1</smiles>

\section{pyrazolidine (7)}

Fig. 2: Basic structure of pyrazole and related compounds

lines. Out of the synthesized compounds, compound $17 \mathrm{t}$ was found to be the most potent anticancer candidate with $\mathrm{IC}_{50}$ values of 1.09 , 2.71, 3.18, and $13.52 \mu \mathrm{M}$ against Raji, SGC7901, A549, and HeLa, respectively [25].

Discovery of some pyrazoles in the year 2014

Fig. 4 showed new pyrazoles synthesized in 2014. Grosse et al. presented a paper on imidazo[1,2-b]pyrazoles that are useful as inhibitors of 5 human and 1 murine cancer cell lines [26]. Of the 39 compounds screened in vitro by MTT assay, compound 18a, 18b, 19, and 20 displayed an $\mathrm{IC}_{50}$ below $10 \mu \mathrm{M}$. The structure-activity relationship analysis resulted preliminary conclusion that $\mathrm{C}-7$ aminomethylated compounds containing 6-membered cycle like $\mathrm{N}$-methylpiperazine or morpholine have high anticancer potency. On the contrary, in C-2/C3/C-6/C-7 tetrasubstituted imidazo[1,2-b]pyrazoles, the presence of a fourth substituent has not influence to enhance the anticancer activity, except in the case of compound 20 [26].

The synthesis and inhibitory activity against A549 lung cancer cell line of a series of 2-(3,5-dimethyl-1H-pyrazol-1-yl)-1-arylethanones were described by Kumar et al. [27]. In vitro anticancer test was performed against colon (HCT-116 and HT-29), lung (A549), prostate (DU-145), and ovarian (SKOV3) cell lines. Compound 21a was found to be cytotoxic to all cancer cell lines, except SKOV3. Furthermore, compound 21a and $21 \mathrm{~b}$ exhibited similar activity as carboplatin in inhibiting viability of A549 cancer cell line [27]. Li et al. reported the synthesis of 4-pyrazolyl1,8-naphthalimide derivatives (22a-l) [28]. All compounds were toxic against MCF-7 and HeLa that have $\mathrm{IC}_{50}$ values of $0.51-17.01 \mu \mathrm{M}$ (on 


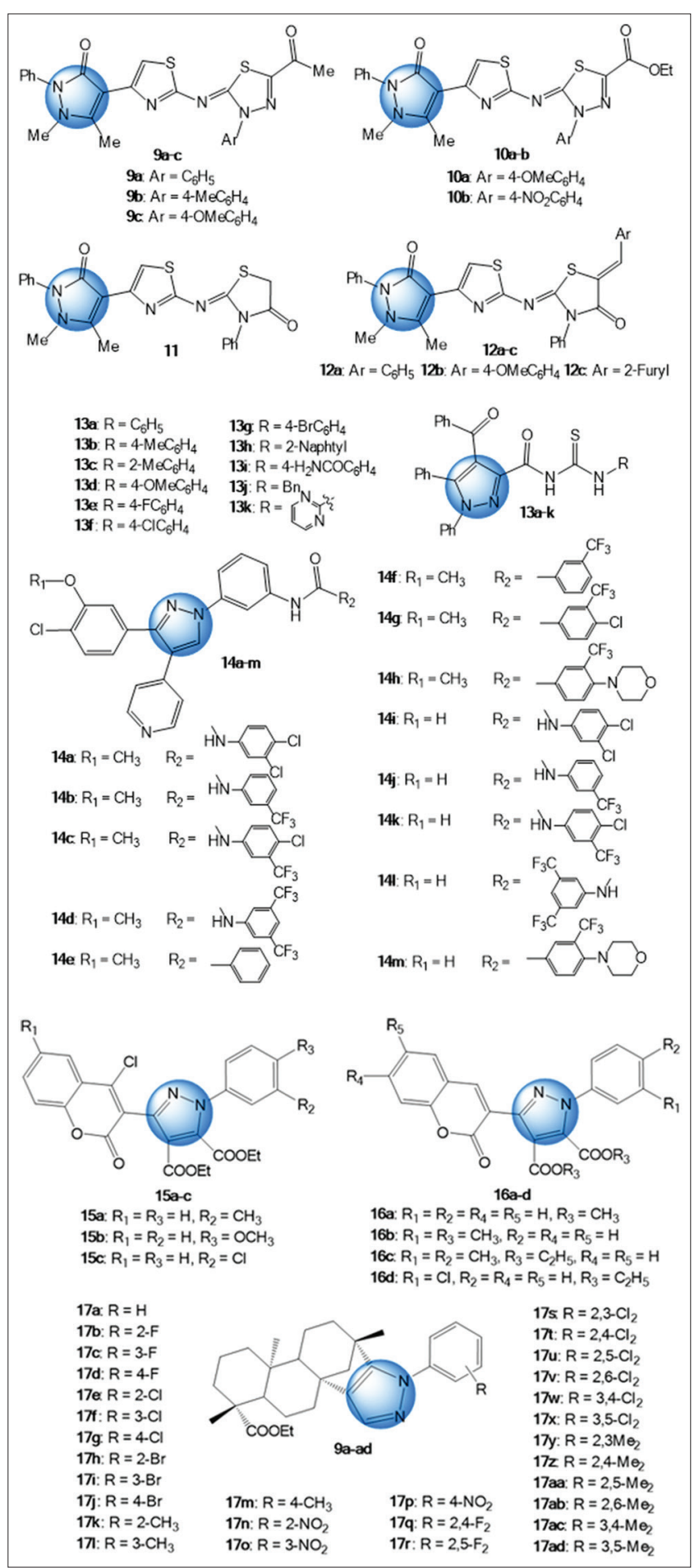

Fig. 3: Pyrazole derivatives discovered during the year 2013

MCF-7) and 3.09-16.60 $\mu \mathrm{M}$ (on HeLa). Toward these cells, compound $22 \mathrm{~b}, 22 \mathrm{~h}$, and $22 \mathrm{i}$ have higher cytotoxicity than amonafide (control). On A549 cell, most of the synthesized compounds have good anticancer activity $\left(\mathrm{IC}_{50}\right.$ values between 5.09 and $25.36 \mu \mathrm{M}$ ), except compound $22 \mathrm{~d}$ and 22l, displayed $\mathrm{IC}_{50}$ values more than $50 \mu \mathrm{M}$ [28].

The compounds of 5-(p-tolyl)-1-(quinoline-2-yl)pyrazole-3-carboxylic acid amides with potent antiproliferative activity against human liver, breast, and colon carcinoma cancer cell lines were developed by Pirol et al. [29]. In the series that contain 15 synthesized bioactive molecules, compound 23 with 2-chloro-4-pyridinyl group in the amide part showed promising cytotoxic performance against all the abovementioned cancer cell lines with $\mathrm{IC}_{50}$ values of $1.6 \mu \mathrm{M}$ (on liver cancer cell), $3.3 \mu \mathrm{M}$ (on breast cancer cell), and $1.1 \mu \mathrm{M}$ (on colon carcinoma cancer cell). It induced apoptosis with significant cell cycle arrest at SubG1/G1 phase in human liver cancer cell line.

A series of derivative compounds which contain pyrazole-thiazolenaphthalene hybrid was synthesized by Yuan et al. [30]. Of the 28 compounds evaluated, $30 \mathrm{~d}$ exhibited the most potent inhibitory activity against HeLa with $\mathrm{IC}_{50}$ of $0.86 \mu \mathrm{M}$. SAR analysis revealed that the presence of electron donating group enhanced the antiproliferative activity $(-\mathrm{OMe}>-\mathrm{Me}>-\mathrm{H}>-\mathrm{Br}>-\mathrm{Cl}>-\mathrm{F})$. Moreover, compound with 4-thiazolinone moiety displayed higher inhibitory activity than compound bearing a 4-phenylthiazolinone group.

\section{Discovery of some pyrazoles in the year 2015}

El-Karim et al. discovered a novel series of benzofuran-pyrazole derivatives as anticancer agents [31]. Resultantly, compound 31a exhibited a notable anticancer activity against Leukemia CCRF-CEM, MOLT-4, ovarian cancer IGROV1, CNS cancer SNB-75, melanoma SK-MEL-2, colon cancer HCC-2998, renal cancer 786-0, RXF 393, lung cancer HOP-92, breast cancer HS 578T, and T-47D lines with IC $_{50}$ values between 1.00 and $2.71 \mu \mathrm{M}$. Molecular docking study revealed that compound 31a has fulfilled Lipinskiís rule of five. Furthermore, good anticancer activity of compound 31a, 31b, and 32 could be attributed to the presence of benzofuran- $\mathrm{N}$-phenylpyrazole skeleton together with the 3-pyrrolo/furano-N-acetyl pyrazoline or 3-pyrrolo-isoxazole ring systems. Kamal et al. developed a series of pyrazole-oxindole conjugates through Knoevenagel condensation [32]. Compound 33a-c was proved to be the three best molecules in inhibiting the cell growth of HeLa, A549, MCF-7, and DU-145 with IC ${ }_{50}$ values in the range of 2.4-9.3 $\mu \mathrm{M}$. The presence of a single chloro or methoxy group at D ring was found to be important for the antiproliferative and antitubulin polymerization activity. Notably, from Zebrafish screening assays showed that compound 33a and 33c caused developmental defect of embryos (Fig. 5).

Among the 1,3-diphenyl-1H-pyrazoles that contain benzimidazole moiety developed by Reddy et al., most of the synthesized compounds significantly inhibit the proliferation of cancer cell and some of them have excellent antiproliferative action than 5-fluorouracil as control [33]. Compound 34a-c demonstrated potent large spectrum cytotoxicity against A549, HeLa, and MCF-7 cancer cell lines with $\mathrm{IC}_{50}$ values in the range of $0.83-1.81 \mu \mathrm{M}$. Compound 35 which has 5 -fluoro-pyridin and 4-fluoro-phenyl moiety showed the highest inhibition in human MCF-7 and HeLa cell lines among the new series of biomolecules synthesized by Sankappa et al. [34]. A new series of steroidal oxadiazole, pyrrole, and pyrazole derivatives was developed by Shamsuzzaman et al. resulted in compound 36 as the most promising anticancer candidate [4]. This study also reported that pyrazole moiety after being attached with steroidal skeleton may be the factor responsible for enhanced anticancer properties of pyrazoles. Various novel pyrazole-5-carboxamide and pyrazolepyrimidine derivatives were synthesized by Shi et al. and were tested for antiproliferative activity against MGC-803, SGC-7901, and Bcap-37 cell lines in vitro [35]. Compound 37 was recorded to be a promising anticancer agent. Several coumarin substituted thiazolyl3-aryl-pyrazole-4-carbaldehydes were designed by Vaarla et al. [36]. Compound 38a and 38b showed an appreciated inhibition against MCF-7, HeLa, and DU-145 cell lines.

\section{Discovery of some pyrazoles in the year 2016}

Two series of substituted phenyl pyrazoles were developed by Alam et al. and were tested as inhibitor for several cancer cell lines [3]. As a result, compound 39 displayed superior cytotoxicity with an $\mathrm{IC}_{50}$ value of $14.31 \pm 0.90 \mu \mathrm{M}$ for MCF-7, $8.55 \pm 0.35 \mu \mathrm{M}$ for NCI-H460, and $7.01 \pm 0.60 \mu \mathrm{M}$ for HeLa. This compound showed in silico 


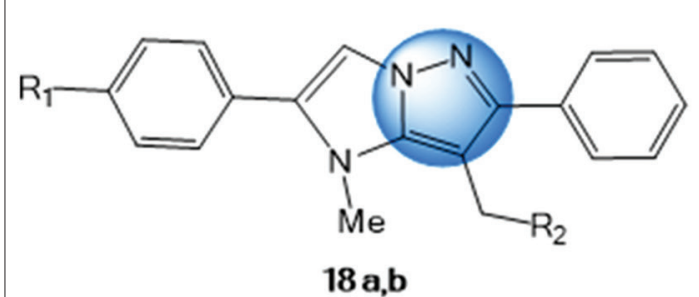

18a $\mathrm{R}_{1}=\mathrm{CH}_{3}, \mathrm{R}_{2}=4$-methylpiperazin-1-yl

18b: $\mathrm{R}_{1}=\mathrm{Cl}, \mathrm{R}_{2}=4$-methylpiperazin-1-yl

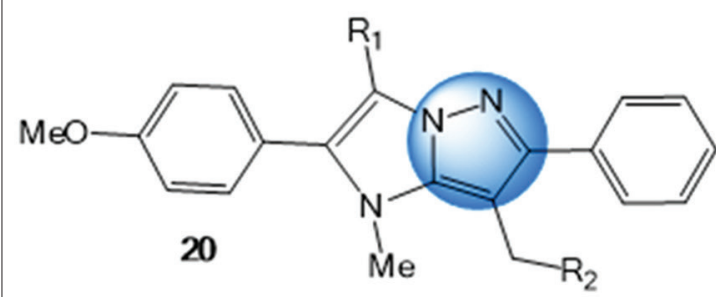

$\mathrm{R}_{1}=4-\mathrm{CF}_{3}-\mathrm{C}_{6} \mathrm{H}_{4}, \mathrm{R}_{2}=4$-morpholin-1-yl

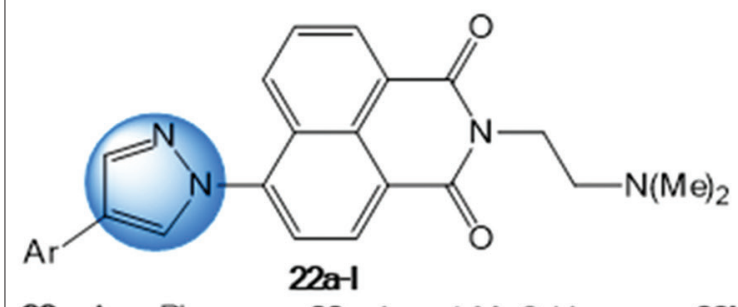

22a $\mathrm{Ar}=\mathrm{Ph} \quad$ 22e $\mathrm{Ar}=4-\mathrm{MeC}_{6} \mathrm{H}_{4}$

22b: $\mathrm{Ar}=4-\mathrm{FC}_{6} \mathrm{H}_{4}$ 22r: $\mathrm{Ar}=4-\mathrm{MeOC}_{6} \mathrm{H}_{4}$

22. $\mathrm{Ar}=4-\mathrm{ClC}_{6} \mathrm{H}_{4} 22 \mathrm{~g} \mathrm{Ar}=3-\mathrm{MeOC}_{6} \mathrm{H}_{4}$

22d: $\mathrm{Ar}=4-\mathrm{BrC}_{6} \mathrm{H}_{4}$ 22h: $\mathrm{Ar}=3,4-(\mathrm{MeO})_{2} \mathrm{C}_{6} \mathrm{H}_{3}$ 22: $\mathrm{Ar}=\mathrm{H}$

22: $\mathrm{Ar}=3,4,5-(\mathrm{MeO}){ }_{3} \mathrm{C}_{6} \mathrm{H}_{2}$

22j: $\mathrm{Ar}=4-\mathrm{CF}_{3} \mathrm{C}_{6} \mathrm{H}_{4}$

22k: $\mathrm{Ar}=3,5-\left(\mathrm{CF}_{3}\right)_{2} \mathrm{C}_{6} \mathrm{H}_{3}$

19
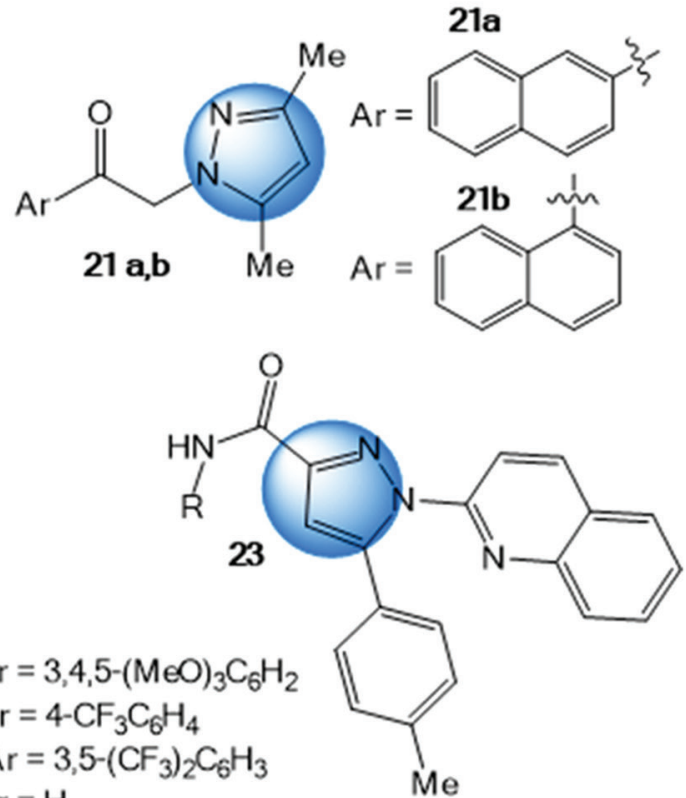

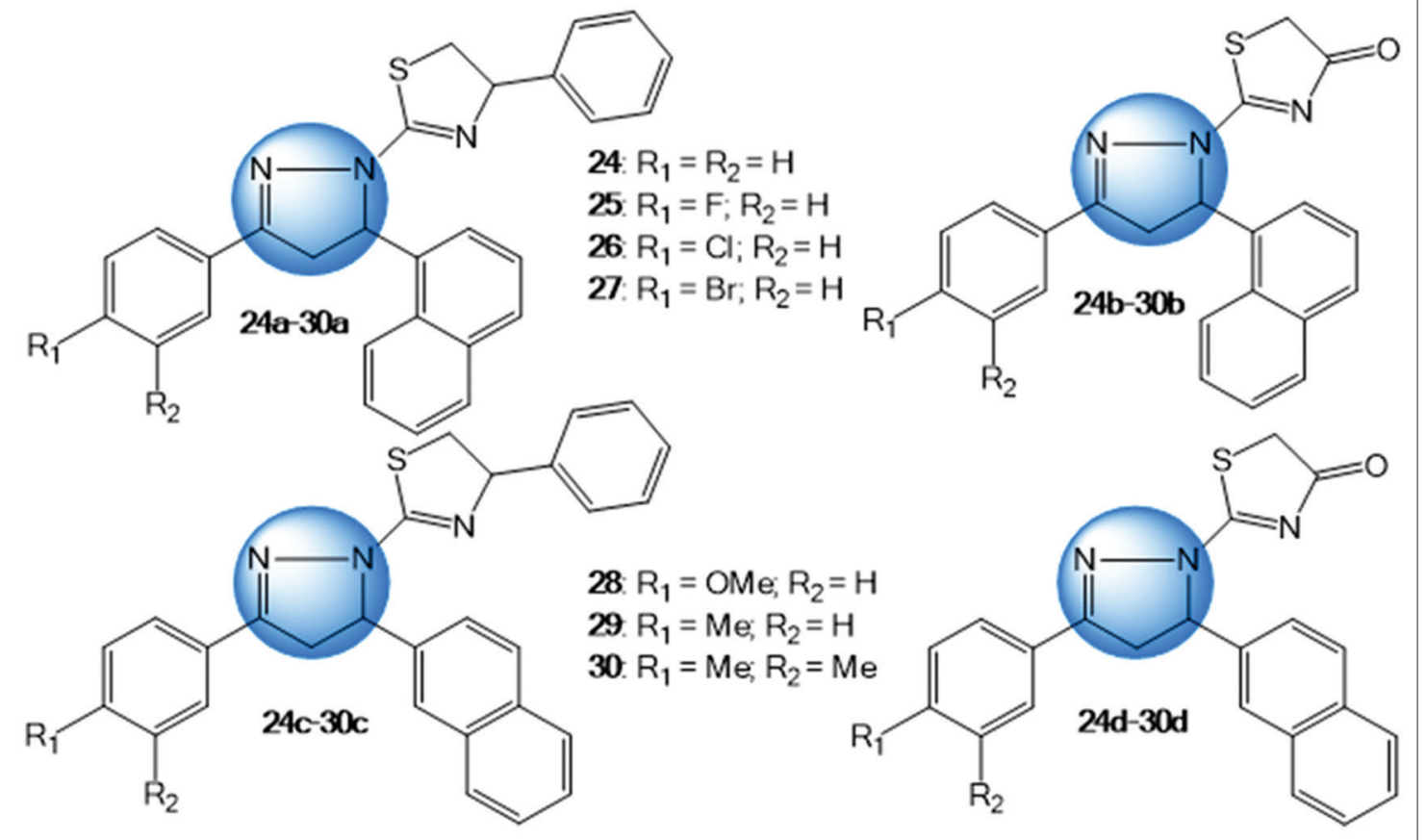

Fig. 4: Pyrazole derivatives discovered during the year 2014

drug-likeliness properties within the acceptable range. Dai et al. synthesized a series of novel pyrazole oxime derivatives containing a 1,2,3-thiadiazole scaffold [37]. Compounds 40a, 40c-e were the most active against HCT-116 cells with $\mathrm{IC}_{50}$ values below $8.50 \mu \mathrm{M}$.
It was better than 5-fluorouracil. In addition, compounds $40 \mathrm{~b}$, $40 \mathrm{~d}$, and $40 \mathrm{e}$ presented good inhibitory performance against SGC-7901 with the $\mathrm{IC}_{50}$ between 8.64 and $11.46 \mu \mathrm{M}$, which were better than 5 -fluorouracil (Fig. 6). 


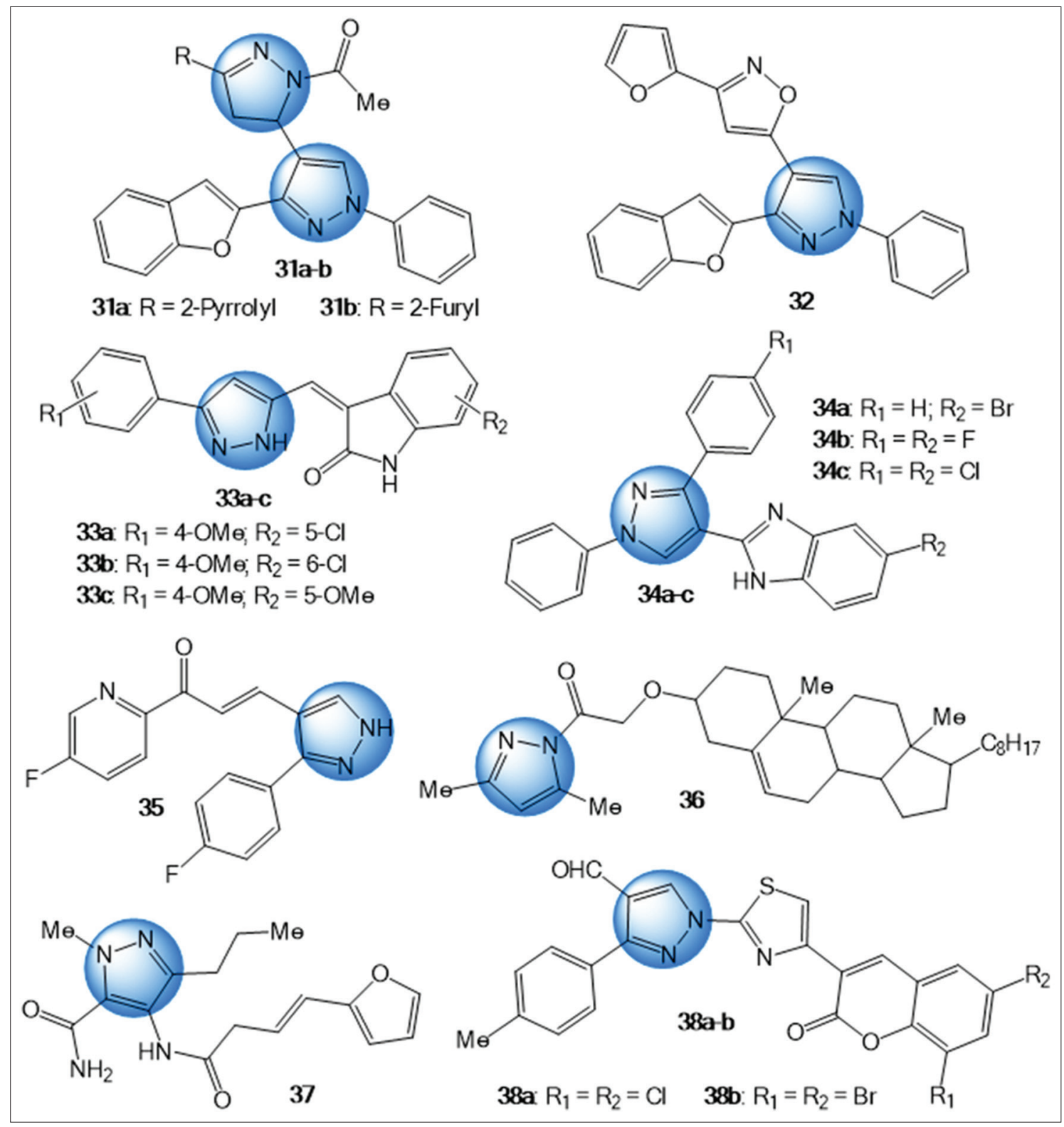

Fig. 5: Pyrazole derivatives discovered during the year 2015

Hafez et al. investigated the synthesis of novel pyrazole derivatives decorated with oxa/thiadiazolyl, pyrazolyl moieties, and pyrazolo[4,3-d] pyrimidines as potential anticancer agents [38]. Among the designed compounds, compounds $41 \mathrm{a}, 41 \mathrm{~b}$, and 42 indicated higher anticancer activity than doxorubicin as standard drug. A novel series of 6-aryl3-methyl-1-phenyl-1H-pyrazolo[3,4-d]pyrimidin-4(5H)-ones were prepared by Rahmouni et al. in a single step through the reaction of carboxamide with several aromatic aldehydes in the presence of iodine [39]. From the results, it was monitored that compound 43 had the highest cytotoxicity against HCT-116 and MCF-7 cancer cell lines at $100 \mu \mathrm{M}$ with $\%$ inhibition values of $75.4 \pm 8.9$ and $72.0 \pm 4.9 \%$, respectively. To the various products evaluated, the HCT-116 colon cell line is more sensitive than MCF- 7 breast cancer cell line. In another research, the development of a small library of 1-acetyl-5-aryl-4,5dihydro-1H-pyrazoles (44a-g) was described by Ratković et al. [40]. Further, it was noted that compounds $44 \mathrm{c}, 44 \mathrm{~d}$, and $44 \mathrm{~g}$ were the most selective inhibitor of HCT-116 cell line. 30 compounds in the series of (Z)-1-(1,3-diphenyl-1H-pyrazol-4-yl)-3-(phenylamino)prop-2-en-1ones were synthesized by Reddy et al. and were investigated against
HT-29, PC-3, A-549, U87MG, and HaCaT cancer cell lines [41]. The compounds $45 \mathrm{a}$-c exhibited an excellent and broad spectrum of growth inhibition on all the tested cancer cells with $\mathrm{IC}_{50}$ values in the range of 1.25-3.98 $\mu$ M. A novel series of selective inhibitor for HGC-27, PC-3, EC109, and MCF-7 was developed by Wang et al. [42]. Indolyl substituted 1,4,6,7-tetrahydropyrano[4,3-c]pyrazoles were synthesized, and from bioactivity studies, it was found that compounds $46 \mathrm{a}$ and $46 \mathrm{~b}$ were the most selective to inhibit MCF-7 cell line with activity close to that of doxorubicin. Compound 46c selectively inhibited the growth of HGC-27 and PC-3 cell lines, whereas compound $46 \mathrm{~d}$ was the most potent for the EC-109 inhibitor.

\section{CONCLUSION AND FUTURE PROSPECT}

The main goal of this review is focused on pyrazole heterocyclic ring decorated with various functional groups. These compounds displayed a large spectrum of biological performance, especially as anticancer agents. Some of them were selective for certain cancer cell line with activity greater than reference drugs. The design and development of anticancer agents become an interesting field of research since cancer 


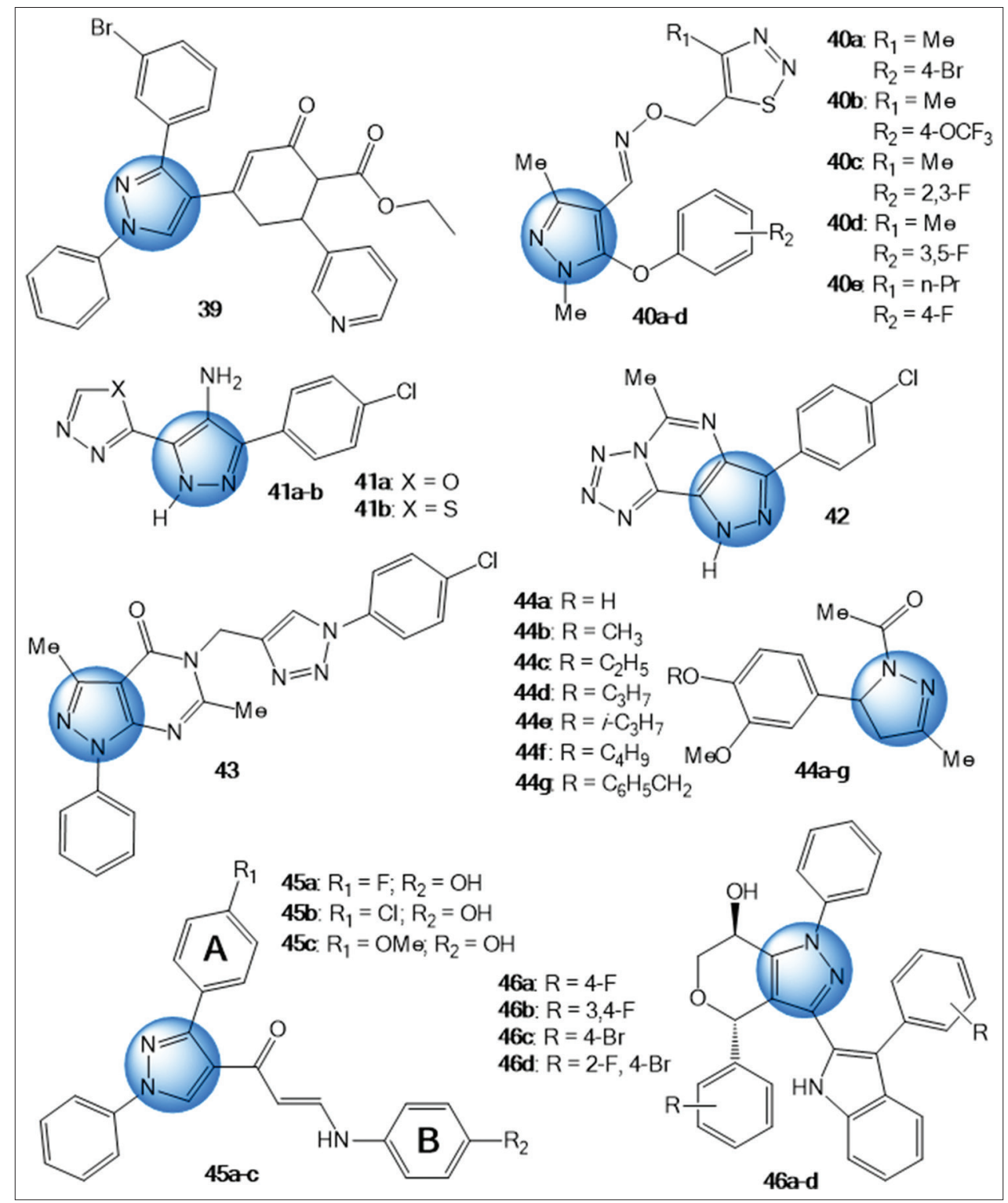

Fig. 6: Pyrazole derivatives discovered during the year 2016

is the deadly disease in the world. In future, we hope researchers will explore new candidates for anticancer through the green organic synthesis of functional molecules.

\section{REFERENCES}

1. Srivastava M, Singh J, Singh SB, Tiwari K, Pathak KV, Singh J. Synthesis of novel fused heterocycle-oxa-aza-phenanthrene and anthracene derivatives via sequential one-pot synthesis in aqueous micellar system. Green Chem 2012;14:901-5.

2. Pai G, Chattopadhyay AP. N-arylation of nitrogen containing heterocycles with aryl halides using copper nanoparticle catalytic system. Tetrahedron Lett 2016;57:3140-5.

3. Alam R, Wahi D, Singh R, Sinha D, Tandon V, Grover A, et al. Design, synthesis, cytotoxicity, Hu Topoll $\alpha$ inhibitory activity and molecular docking studies of pyrazole derivatives as anticancer agents. Bioorg Chem 2016;69:77-90.

4. Shamsuzzaman S, Siddiqui T, Alam MG, Dar AM. Synthesis, characterization and anticancer studies of new steroidal oxadiazole, pyrrole and pyrazole derivatives. J Saudi Chem Soc 2015;19:387-91.

5. Ismail MM, Soliman DH, Farrag AM, Sabour R. Synthesis, antitumor activity, pharmacophore modelling and QSAR studies of novel pyrazoles and pyrazolo[1,5-a]pyrimidines against breast adenocarcinoma MCF-7 cell line. Int J Pharm Pharm Sci 2016;8:434-42.
6. Sony JK, Ganguly S. A battle against AIDS: New pyrazole key to an older lock-reverse transcriptase. Int J Pham Pharm Sci 2016;8:75-9.

7. Surendra Kumar R, Arif IA, Ahamed A, Idhayadhulla A. Antiinflammatory and antimicrobial activities of novel pyrazole analogues. Saudi J Biol Sci 2016;23:614-20.

8. Ningaiah S, Bhadraiah UK, Doddaramappa SD, Keshavamurthy S, Javarasetty C. Novel pyrazole integrated 1,3,4-oxadiazoles: Synthesis, characterization and antimicrobial evaluation. Bioorg Med Chem Lett 2014;24:245-8.

9. Bekhit AA, Hassan AM, Abd El Razik HA, El-Miligy MM, El-Agroudy EJ, Bekhit Ael-D. New heterocyclic hybrids of pyrazole and its bioisosteres: Design, synthesis and biological evaluation as dual acting antimalarial-antileishmanial agents. Eur J Med Chem 2015;94:30-44.

10. Pathak V, Maurya HK, Sharma S, Srivastava KK, Gupta A. Synthesis and biological evaluation of substituted 4,6-diarylpyrimidines and 3,5-diphenyl-4,5-dihydro-1H-pyrazoles as anti-tubercular agents. Bioorg Med Chem Lett 2014;24:2892-6.

11. Kameyama T, Nabeshima T. Effects of 1,3-diphenyl-5-(2dimethylaminopropionamide)-pyrazole[difenamizole] on a conditioned avoidance response. Neuropharmacology 1978;17:249-56.

12. Wyde PR, Gilbert BE, Ambrose MW. Comparison of the anti-respiratory syncytial virus activity and toxicity of papaverine hydrochloride and pyrazofurin in vitro and in vivo. Antiviral Res 1989;11:15-26. 
13. Friedrich G, Rose T, Rissler K. Determination of lonazolac and its hydroxyl and o-sulfated metabolites on-line sample preparation liquid chromatography with fluorescence detection. J Chrmatogr B 2002;786:295-305

14. Pantel J, Williams SY, Mi D, Sebag J, Corbin JD, Weaver CD, et al. Development of a high throughput screen for allosteric modulators of melanocortin-4 receptor signaling using a real time cAMP assay. Eur J Pharmacol 2011;660:139-47.

15. Kumar KA, Jayaroopa P. Pyrazoles: Synthetic strategies and their pharmaceutical applications-an overview. Int J PharmTech Res 2013; 5(4): 1473-1486.

16. Parmar NJ, Pansuriya BR, Labana BM, Sutariya TR, Kant R, Gupta VK. Access to some angular aminochromeno[2,3-c]pyrazole precursor by a domino knoevenagel-hetero-diels-alder reaction. Eur J Org Chem 2012;2012:5953-64

17. Ramiz MM, Hafiz IS, Reheim MA, Gaber HM. Pyrazolones as building blocks in heterocyclic synthesis: Synthesis of new pyrazolopyran, pyrazolopyridazine and pyrazole derivatives of expected antifungicidal activity. J Chin Chem Soc 2012;59:72-80

18. Huang XF, Lu X, Zhang Y, Song GQ, He QL, Li QS, et al. Synthesis, biological evaluation, and molecular docking studies of $\mathrm{N}-((1,3-$ diphenyl-1H-pyrazol-4-yl)methyl)aniline derivatives as novel anticancer agents. Bioorg Med Chem 2012;20:4895-900.

19. Khan MF,Alam MM, Verma G,AkhtarW,Akhter M, Shaquiquzzaman M. The therapeutic voyage of pyrazole and its analogs: A review. Eur J Med Chem 2016;120:170-201.

20. Chen TC, Guh JH, Hsu HW, Chen CL, Lee CC, Wu CL, et al. Synthesis and biological evaluation of anthra[1,9-cd]pyrazol-6(2H)-one scaffold derivatives as potential anticancer agents. Arab J Chem 2015;7:914-23.

21. Dawood KM, Eldebss TM, El-Zahabi HS, Yousef MH, Metz P. Synthesis of some new pyrazole-based 1,3-thiazoles and 1,3,4-thiadiazoles as anticancer agents. Eur J Med Chem 2013;70:740-9.

22. Koca I, Özgür A, Coskun KA, Tutar Y. Synthesis and anticancer activity of acyl thioureas bearing pyrazole moiety. Bioorg Med Chem 2013;21:3859-65.

23. El-Gamal MI, Park YS, Chi DY, Yoo KH, Oh CH. New triarylpyrazoles as broad-spectrum anticancer agents: Design, synthesis, and biological evaluation. Eur J Med Chem 2013;65:315-22.

24. Kumar JA, Saidachary G, Mallesham G, Sridhar B, Jain N, Kalivendi SV, et al. Synthesis, anticancer activity and photophysical properties of novel substituted 2-oxo-2H-chromenylpyrazolecarboxylates. Eur J Med Chem 2013;65:389-402.

25. Zhu SL, Wu Y, Liu CJ, Wei CY, Tao JC, Liu HM. Design and stereoselective synthesis of novel isosteviol-fused pyrazolines and pyrazoles as potential anticancer agents. Eur J Med Chem 2013;65:70-82.

26. Grosse S, Mathieu V, Pillard C, Massip S, Marchivie M, Jarry C, et al. New imidazo[1,2-b]pyrazoles as anticancer agents: Synthesis, biological evaluation and structure activity relationship analysis. Eur J Med Chem 2014:84:718-30.

27. Kumar V, Kaur K, Karelia DN, Beniwal V, Gupta GK, Sharma AK, et al. Synthesis and biological evaluation of some 2-(3,5-dimethyl-1Hpyrazol-1-yl)-1-arylethanones: Antibacterial, DNA photocleavage, and anticancer activities. Eur J Med Chem 2014;81:267-76.

28. Li S, Xu S, Tang Y, Ding S, Zhang J, Wang S, et al. Synthesis, anticancer activity and DNA-binding properties of novel 4-pyrazolyl1,8-naphtalimide derivatives. Bioorg Med Chem Lett 2014;24:586-90.

29. Cankara Pirol S, Çaliskan B, Durmaz I, Atalay R, Banoglu E. Synthesis and preliminary mechanistic evaluation of 5-(p-tolyl)-1-(quinolin-2-yl) pyrazole-3-carboxylic acid amides with potent antiproliferative activity on human cancer cell lines. Eur J Med Chem 2014;87:140-9.

30. Yuan JW, Wang SF, Luo ZL, Qiu HY, Wang PF, Zhang X, et al. Synthesis and biological evaluation of compounds which contain pyrazole, thiazole and naphthalene ring as antitumor agents. Bioorg Med Chem Lett 2014;24:2324-8.

31. Abd El-Karim SS, Anwar MM, Mohamed NA, Nasr T, Elseginy SA. Design, synthesis, biological evaluation and molecular docking studies of novel benzofuran-pyrazole derivatives as anticancer agents. Bioorg Chem 2015;63:1-12.

32. Kamal A, Shaik AB, Jain N, Kishor C, Nagabhushana A, Supriya B, et al. Design and synthesis of pyrazole-oxindole conjugates targeting tubulin polymerization as new anticancer agents. Eur J Med Chem 2015;92:501-13

33. Reddy TS, Kulhari H, Reddy VG, Bansal V, Kamal A, Shukla R. Design, synthesis and biological evaluation of 1,3-diphenyl-1H-pyrazole derivatives containing benzimidazole skeleton as potential anticancer and apoptosis inducing agents. Eur J Med Chem 2015;101:790-805.

34. Sankappa RU, Isloor AM, Shetty P, Pai KS, Fun HK. Synthesis and in vitro biological evaluation of new pyrazole chalcone and heterocyclic diamides as potential anticancer agents. Arab J Chem 2015;8:317-21.

35. Shi JB, Tang WJ, Qi XB, Li R, Liu XH. Novel pyrazole-5-carboxamide and pyrazole-pyrimidine derivatives: Synthesis and anticancer activity. Eur J Med Chem 2015;90:889-96.

36. Vaarla K, Kesharwani RK, Santosh K, Vedula RR, Kotamraju S, Toopurani MK. Synthesis, biological activity evaluation and molecular docking studies of novel coumarin substituted thiazolyl-3-arylpyrazole-4-carbaldehydes. Bioorg Med Chem Lett 2015;25:5797-803.

37. Dai H, Ge S, Li G, Chen J, Shi Y, Ye L, et al. Synthesis and bioactivities of novel pyrazole oxime derivatives containing a 1,2,3-thiadiazole moiety. Bioorg Med Chem Lett 2016;26:4504-7.

38. Hafez HN, El-Gazzar AR, Al-Hussain SA. Novel pyrazole derivatives with oxa/thiadiazolyl, pyrazolyl moieties and pyrazolo[4,3-d]pyrimidine derivatives as potential antimicrobial and anticancer agents. Bioorg Med Chem Lett 2016;26:2428-33.

39. Rahmouni A, Souiei S, Belkacem MA, Romdhane A, Bouajila J, Ben Jannet H. Synthesis and biological evaluation of novel pyrazolopyrimidines derivatives as anticancer and anti-5-lipoxygenase agents. Bioorg Chem 2016;66:160-8.

40. Ratković Z, Muškinja J, Burmudžija A, Ranković B, Kosanić M, Bogdanović GA, et al. Dehydrozingerone based 1-acetyl-5-aryl-4,5dihydro-1H-pyrazoles: Synthesis, characterization and anticancer activity. J Mol Struct 2016;1109:82-8.

41. Srinivasa Reddy T, Ganga Reddy V, Kulhari H, Shukla R, Kamal A, Bansal V. Synthesis of (Z)-1-(1,3-diphenyl-1H-pyrazol-4yl)-3-(phenylamino)prop-2-en-1-one derivatives as potential anticancer and apoptosis inducing agents. Eur J Med Chem 2016;117:157-66.

42. Wang FQ, Yang H, He B, Jia YK, Meng SY, Zhang C, et al. A novel domino approach for synthesis of indolyl tetrahydropyrano[4,3-c] pyrazole derivatives as anticancer agents. Tetrahedron 2016;72:5769-75. 